\title{
Ekonomia społeczna jako ważne ogniwo w systemie wsparcia rodziny
}

\begin{abstract}
Katarzyna Jagielska*, Józefa Matejek**
Streszczenie: Zagadnienia dotyczące przeobrażeń współczesnej rodziny są jednym z ważnych problemów w obszarze polityki społecznej. W niniejszym artykule skupiono się na problemach wynikających z przemian demograficznych - zwłaszcza starzenia się ludności, konsekwencją których jest wzrost znaczenia funkcji opiekuńczej rodziny względem najstarszych jej członków. Istotną rolę w tym obszarze odgrywa także ekonomia społeczna, stając się ważnym czynnikiem w systemie pomocy i wsparcia rodziny. Przedsiębiorstwa społeczne mogą wspierać rodziny poprzez świadczenie usług opiekuńczych na rzecz osób starszych. Jest to istotny aspekt działań w obliczu starzenia się społeczeństwa polskiego. Wraz z wiekiem spada sprawność funkcjonalna, pojawia się wielochorobowość, a to skutkuje zapotrzebowaniem na usługi opiekuńcze na rzecz osób starszych. Usługi dedykowane seniorom w ramach systemów pomocy społecznej i ochrony zdrowia nie zaspokajają potrzeb wszystkich osób, które ich potrzebują, stąd konieczność poszukiwania nowych rozwiązań w tym zakresie.
\end{abstract}

Słowa kluczowe: wsparcie społeczne, ekonomia społeczna, rodzina, senior, opieka nad seniorem.

\section{Wprowadzenie}

Współczesne trendy demograficzne skłaniają do zmian kierunku rozwoju polityki społecznej, która powinna skoncentrować się na działaniach wspierających rodzinę, w bardzo szerokim tego słowa znaczeniu. Wynika to z faktu transformacji modelu rodziny wywołanego m.in. zmianami: struktury rodziny, w zakresie prokreacji, w częstotliwości i wieku zawierania małżeństw, w liczbie rozwodów, wielkości oraz struktury „sieci rodzinnej”. Przemianom ulegają role rodzinne kobiet i mężczyzn, zmiana pozycji dziecka oraz osób starszych w rodzinie [Kurowska, 2011]. Procesy demograficzne związane $z$ kwestiami starzenia się oraz długości życia ludności wpływają także na przeobrażenia funkcji rodziny, w tym również funkcji opiekuńczej. Wydłużanie się średniego czasu trwania życia sprawia, że obecnie w rodzinie opieki wymagają nie tylko dzieci, ale także starzejący się z czasem rodzice, jak również najstarsi jej członkowie - seniorzy-dziadkowie. Zmiany te powinny skłaniać do refleksji nad kierunkami rozwoju polityki społecznej państwa. Celem niniejszego artykułu jest wskazanie najważniejszych obszarów, w których ekonomia społeczna może wspierać rodzinę i seniora. W prezentowanym opracowaniu posłużono się wtórną analizą źródeł.

\footnotetext{
* Katarzyna Jagielska Instytut Pracy Socjalnej Wydział Pedagogiczny Uniwersytet Pedagogiczny im. KEN w Krakowie os. Stalowe 17, 31-922 Kraków e-mail: katarzyna.jagielska@up.krakow.pl

** Józefa Matejek Instytut Pracy Socjalnej Wydział Pedagogiczny Uniwersytet Pedagogiczny im. KEN w Krakowie os. Stalowe 17, 31-922 Kraków e-mail: jozefa.matejek@up.krakow.pl
} 


\section{Wsparcie społeczne względem rodziny - podstawowe rodzaje}

Współczesna rodzina doświadcza skutków procesów transformacji oraz globalizacji, podlega także istotnym przemianom o charakterze społeczno-ekonomiczno-kulturowym. W związku z tym pojawiaja się przed nią nie tylko nowe wyzwania, ale również czynniki zagrażające jej prawidłowemu funkcjonowaniu. Dostrzegamy także zjawisko zwiększania się liczby osób i rodzin wymagających wielowymiarowego wsparcia. Z pomocą przychodzą wówczas instytucje, które podejmują zadania wspierające, realizując jednocześnie przypisane sobie ustawowe i statutowe działania.

Wsparcie społeczne może odnosić się do każdej trudnej sytuacji, w której znajduje się osoba lub rodzina, bez względu na to, czy jest to chwilowa, czy też przedłużająca się w czasie okoliczność, w której jednostka nie potrafi samodzielnie się odnaleźć i często szuka pomocy w gronie bliskich osób: rodziny, przyjaciół, znajomych, ale pomimo podejmowanych prób niejednokrotnie nie jest w stanie do końca rozwiązać zaistniałych problemów. Odwołując się do literatury przedmiotu można dostrzec interdyscyplinarny charakter pojęcia „wsparcie społeczne". Każda z dziedzin nauki będzie w swoim podejściu i terminologii zwracać uwagę na inne aspekty, ponieważ "wsparcie społeczne należy do kluczowych terminów z zakresu pedagogiki społecznej, pracy socjalnej, promocji i ochrony zdrowia oraz psychologii społecznej, a także działalności terapeutycznej" [Kawula, 1999, s. 338]. A. Olubiński określa wsparcie społeczne uwzględniając jego cele, ponieważ „bezpośrednim celem wsparcia byłoby dążenie do włączenia podopiecznego $\mathrm{w}$ proces rozwiązywania problemów. Natomiast trwałym efektem tych działań powinno być ukształtowanie postaw samodzielności, aktywności, a także wyposażenie podopiecznego w konkretne umiejętności pokonywania określonych trudności" [Olubiński, 1997, s. 25]. W zależności od zaistniałej sytuacji wsparcie może przybierać różne rodzaje. S. Kawula wymieniał następujące formy wsparcia: emocjonalne, wartościujące, instrumentalne, informacyjne oraz duchowe [Kawula, 1999, s. 339]. Wymienione rodzaje wsparcia mogą być realizowane przez osoby pochodzące z najbliższego środowiska jednostki, jak również przez osoby, które udzielają wsparcia jako pracownicy instytucji. Można zatem wskazać wsparcie naturalne, którego źródłem jest rodzina, rówieśnicy, znajomi, sąsiedzi, oraz instytucjonalne - świadczone przez instytucje, stowarzyszenia, fundacje, które zajmują się niesieniem pomocy jednostkom znajdującym się w sytuacji trudnej. Nieco inne rozróżnienie rodzajów wsparcia proponuje A. Maciarz, która wymienia wsparcie emocjonalne, informacyjne, materialne, wychowawcze, opiekuńcze, terapeutyczne, usługowe i prawne [Maciarz, 2005, s.109].

Wymienione rodzaje wsparcia oraz sposoby ich praktycznej realizacji uzależnione są zarówno od sytuacji jednostki, której udzielamy wsparcia i jej oczekiwań, jak również działań osób, które występują w roli wspierających. Warto podkreślić, że udzielane długotrwałe wsparcie może w konsekwencji spowodować negatywne rezultaty wynikające z przyzwyczajenia, braku własnej inicjatywy do działania i postawy oczekującej ze strony biorcy. O skuteczności podejmowanych działań wspierających decyduje przede wszystkim spójność pomiędzy rodzajem udzielanego wsparcia a problemami osoby, której niesiona jest pomoc.

W Polsce istnieje wiele instytucji, które w założeniach swojej działalności mają różne aspekty pomocy i wsparcia współczesnej rodziny. Osoby/rodziny znajdujące się w trudnej sytuacji materialnej obejmowane są formami wsparcia w ramach ustawy o pomocy społecznej, w której art. 2.1 znajdziemy zapis, iż „pomoc społeczna jest instytucją polityki 
społecznej państwa, mającą na celu umożliwienie osobom i rodzinom przezwyciężanie trudnych sytuacji życiowych, których nie są one w stanie pokonać, wykorzystując własne uprawnienia, zasoby i możliwości"1. W tym obszarze ustawodawca przyjmuje możliwość udzielania wsparcia między innymi w formie przyznawania i wypłacania przewidzianych ustawą świadczeń, pracy socjalnej, realizacji zadań wynikających z rozeznanych potrzeb społecznych oraz prowadzeniu i rozwoju niezbędnej infrastruktury socjalnej. Ustawowy obowiązek wspierania rodziny przeżywającej trudności w zakresie ustalonym ustawą spoczywa na jednostkach samorządu terytorialnego oraz na organach administracji rządowej.

W zależności od zaistniałej sytuacji na mocy prawa rodziny mogą być objęte także wsparciem zgodnie z ustawą o wspieraniu rodziny i systemie pieczy zastępczej ${ }^{2}$, która koncentruje się m.in. na działaniach skierowanych do rodzin z dziećmi przeżywających trudności w wypełnianiu funkcji opiekuńczo-wychowawczych, a także na zasadach i formach sprawowania pieczy zastępczej. Zgodnie $z$ art. 8.2 ww. ustawy ,wspieranie rodziny jest prowadzone $w$ formie: 1 ) pracy z rodziną; oraz 2) pomocy w opiece i wychowaniu dziecka". Dodatkowo rodziny z dziećmi mogą uzyskać pomoc państwa zgodnie z ustawą o pomocy państwa w wychowywaniu dzieci ${ }^{3}$, która określa warunki nabywania prawa do świadczenia wychowawczego oraz zasady przyznawania i jego wypłacania. Program "Rodzina 500 plus" to wsparcie finansowe w kwocie 500,00 zł miesięcznie na każde drugie i kolejne dziecko, bez dodatkowych warunków. Rodziny o niskich dochodach otrzymują wsparcie także na pierwsze lub

Ustawa z dnia 12 marca 2004 roku o pomocy społecznej (Dz. U. 2004 nr 64 poz. 593).

Ustawa z dnia 9 czerwca 2011 roku o wspieraniu rodziny i systemie pieczy zastępczej (Dz.U. 2013 poz. 135 z późn. zm.). Ustawa z dnia 11 lutego 2016 r. o pomocy państwa w wychowywaniu dzieci (Dz.U. 2016 poz. 195). jedyne dziecko, przy spełnieniu kryterium dochodu rodziny $w$ przeliczeniu na osobę nie przekraczającym kwoty 800,00 zł netto lub 1200,00 zł w przypadku wychowywania $w$ rodzinie dziecka niepełnosprawnego. Według art. 4 tejże ustawy „,celem świadczenia wychowawczego jest częściowe pokrycie wydatków związanych z wychowywaniem dziecka, w tym z opieką nad nim i zaspokojeniem jego potrzeb życiowych. Świadczenie wychowawcze przysługuje matce, ojcu, opiekunowi faktycznemu dziecka albo opiekunowi prawnemu dziecka". Świadczenie wychowawcze przysługuje do dnia ukończenia przez dziecko 18. roku życia.

Coraz większe znaczenie w obszarze wsparcia odgrywają także organizacje pozarządowe działające w obszarze pomiędzy instytucjami państwowymi a sektorem prywatnym. Istota ich działalności polega na tym, że niejednokrotnie oczekuje się od nich rozwiązania różnych problemów, które w danym środowisku stanowią ważne kwestie społeczne, a nie są rozwiązane przez jednostki sektora państwowego. Główne obszary działania organizacji pozarządowych to pomoc społeczna, ochrona zdrowia, oświata, edukacja, ekologia, dlatego są one postrzegane jako ważne i znaczące ogniwo w systemie wsparcia instytucjonalnego. Jako przykład takiej działalności można podać Polski Czerwony Krzyż (PCK), który przygotowuje siostry PCK do sprawowania opieki nad osobami chorymi i niepełnosprawnymi w ich domach. Aby uzyskać pomoc, należy zgłosić się do ośrodka pomocy społecznej (zarządy różnych szczebli PCK podpisują umowy na świadczenie takich usług z samorządami terytorialnymi). Ustalenie godzin i zakresu opieki, ewentualnej stawki odpłatności, załatwienie wszystkich formalności odbywa się w porozumieniu pomiędzy OPS, punktem opieki PCK a osobą potrzebującą opieki (lub członkiem rodziny) ${ }^{4}$.

www.pck.pl. 
Należy podkreślić, iż potrzeby w zakresie udzielanego wparcia osobom i rodzinom są ogromne i niejednokrotnie wymagają podejmowania szerokich działań i współpracy na poziomie instytucjonalnym i społecznym.

\section{Polityka społeczna - nowe wyzwania wobec starzenia się ludności}

Zgodnie z definicją zaproponowaną przez B. Szatur-Jaworską „polityka społeczna jest celową (co nie oznacza, że trafną i skuteczną) działalnością podejmowaną przez podmioty życia politycznego i społecznego - wśród których kluczowa rola przypada państwu - mającą prowadzić do realizacji różnorako określanych celów społecznych" [Szatur-Jaworska, 2016, s. 71]. Cele realizowane przez politykę społeczną można wyznaczyć na podstawie definicji, w których istotę stanowią następujące pojęcia: „dobrobyt (społeczny), potrzeby, bezpieczeństwo socjalne, (socjalne) prawa człowieka, sprawiedliwość społeczna, struktura społeczna, integracja społeczna, kwestie społeczne oraz postęp i rozwój społeczny" [ibidem, 2016, s. 72]. Cele realizowane przez politykę społeczną mają zatem dbać o interes jednostek, dążyć do tego, żeby zapewnić jednostce jak najlepsze funkcjonowanie w społeczeństwie oraz zapewnić poczucie bezpieczeństwa.

Jak już zostało wspomniane, kluczowym wyzwaniem dla polityki społecznej państwa są kwestie wynikające z przemian współczesnej rodziny oraz demograficznego starzenia się społeczeństwa. System wsparcia współczesnej rodziny koncentruje się na pomaganiu jej także poprzez m.in. system świadczeń rodzinnych, system podatkowy oraz program „Rodzina 500+". Mają one na celu wsparcie w realizacji funkcji ekonomicznej oraz opiekuńczej rodziny. System świadczeń wspiera również funkcje wychowawcze (wprowadzenie rocznego urlopu macierzyńskiego, urlopu ojcowskiego, możliwość korzystania z urlopu wychowawczego), edukacyjne itp. Proponowane rozwiązania kierowane są jednak głównie do rodziny, w której wychowuje się małe dzieci. W systemie wsparcia pomijana jest funkcja opiekuńcza rodziny w znaczeniu opieki nad starszym rodzicem. Funkcje rodziny ujmuje się jako wzajemne powiązania członków rodziny, które dotyczą różnych sfer życia rodziny i są wypełniane w różnym zakresie i na różnym poziomie możliwości poszczególnych jej członków. W typologiach, które pojawiają się w literaturze przedmiotu możemy spotkać wiele klasyfikacji funkcji rodziny, niemniej jednak autorzy najczęściej wskazują funkcje: biologiczne, opiekuńcze, kulturalno-towarzyskie, ekonomiczne, socjopsychologiczne, wychowawcze [por. Kawula, 1999; Tyszka, 1991]. Stąd też podkreślany przez nas aspekt funkcji opiekuńczych w tym kontekście nabiera szczególnego znaczenia i dlatego w polityce społecznej nie powinno zabraknąć kwestii wsparcia działalności opiekuńczej. Niestety ten element pomocy rodzinie pozostaje niedostrzegany, a sprawy opieki nad osobami starszymi pozostają nadal problemem rodziny. Państwo nie oferuje $w$ tym obszarze wsparcia finansowego rodzinie. Słaby nacisk kładzie się również na działania wspierające funkcje opiekuńcze rodziny w tej kwestii. Tymczasem dane demograficzne nie pozostawiają złudzeń. Polsce grozi „siwe tsunami" i już teraz powinno się podejmować działania mające na celu złagodzenie skutków szybkiego tempa starzenia się ludności naszego kraju. W 2014 r. odsetek osób powyżej 60 r.ż. w populacji przekroczył 22\%. Dla porównania odsetek dzieci i młodzieży w 2014 r. wynosił 18\%. Największy odsetek wśród subpopulacji osób starszych stanowią osoby w wieku 60-64 lata (6,9\%) oraz 65-69 lat $(5,1 \%)$. Istotny z punktu widzenia demografii, a w konsekwencji również polityki społecznej jest fakt, że największy przyrost w subpopulacji osób starszych zaobserwowano wśród grupy wiekowej 80 lat i więcej. 
Na przestrzeni lat 1989-2014 liczba tych osób podwoiła się, czyli wzrosła z 2\% do 4\% [WHO, 2011]. Nie jest to jednak zjawisko występujące tylko w Polsce. Według danych Światowej Organizacji Zdrowia odsetek osób starszych na świecie wzrasta w coraz szybszym tempie. Przewiduje się, że do 2050 r. nastąpi wzrost o 188\% liczby osób starszych powyżej 65 lat, o 351\% seniorów powyżej 85 r.ż oraz o 1003\% odsetek osób powyżej 100 lat [GUS, 2016]. Według danych szacunkowych Głównego Urzędu Statystycznego prognozy demograficzne obejmujące okres do 2050 r. wskazują, że nastąpi zmniejszenie się liczby dzieci i osób dorosłych, natomiast będzie obserwowany wzrost odsetka osób powyżej 65 r.ż. i w 2050 r. będzie on wynosił ok. 30\% [GUS, 2016]. Dane te są alarmujące i jednoznacznie wskazują na potrzebę, a nawet konieczność, nowych rozwiązań dotyczących wsparcia osób starszych.

Polityka społeczna już teraz powinna skoncentrować się na działaniach dotyczących pomocy osobom starszym i ich rodzinom. Wsparcia wymagać będzie bowiem nie tylko starszy człowiek, ale również rodzina, która będzie mieć pod opieką seniora. Jak podkreśla B. Szatur-Jaworska, starzenie się ludności wywołuje zmiany we wszystkich sferach życia społecznego. Wprowadza ona pojęcie polityki społecznej wobec starzenia się ludności, które definiuje jako „celową działalność podejmowaną przez różne podmioty - wśród, których kluczowa rola przypada państwu - mająca prowadzić do rozwiązywania problemów publicznych i realizacji celów społecznych wynikających ze zmian w strukturze wieku ludności" [Szatur-Jaworska, 2016, s. 71].

\section{Ekonomia społeczna na rzecz wsparcia rodziny i seniora}

W obszarze wsparcia rodzin mających pod opieką starszych członków rodziny istotną rolę może odegrać ekonomia społeczna, która zgodnie z definicją zaproponowaną w Krajowym Programie Rozwoju Ekonomii Społecznej (KPRES) jest sferą „aktywności obywatelskiej, która poprzez działalność ekonomiczną i działalność pożytku publicznego służy: integracji zawodowej i społecznej osób zagrożonych społeczną marginalizacją, tworzeniu miejsc pracy, świadczeniu usług społecznych użyteczności publicznej" [KPRES, 2014]. Ekonomia społeczna na zasadzie komplementarnej może wspierać politykę społeczną w następujących obszarach [Pankiv, Duranowski, 2014]:

- rozwijanie wartości takich jak solidarność i odpowiedzialność społeczna,

- połączenie członków, użytkowników i interesu ogólnego,

- prymat celów osobowych i społecznych nad kapitałem,

- demokratyczna kontrola i przeznaczanie nadwyżki na cele społeczne.

Założenia te stanowią wyznacznik do wsparcia roli opiekuńczej rodziny zajmującej się seniorem. W kontekście problemu starzenia się ludności zarówno rodzina, jak i senior będą wymagali kompleksowego wsparcia. Dotyczyć to będzie zarówno usług opiekuńczych, zdrowotnych, edukacyjnych, jak również aktywizacji zawodowej. W tym kontekście istotną rolę może odegrać ekonomia społeczna, która spełnia w szczególności następujące funkcje [Sałustowicz, 2006, za: Pikuła, Jagielska, 2014]:

- tworzenie nowych miejsc pracy skierowanych do grup zagrożonych wykluczeniem społecznym, a także podjęcie działań dotyczących świadczenia usług m.in. w zakresie doradztwa zawodowego, szkoleń zawodowych, staży, a także innych działań umożliwiających wejście na pierwszy rynek pracy;

- dostarczanie usług socjalnych dla jednostek i wspólnot lokalnych, zwłaszcza tam, gdzie sektor prywatny i publiczny nie są w stanie zaspokoić rosnących potrzeb społecznych; 
- wpływ na rozwój społeczności lokalnych;

- reintegracja społeczna i zawodowa osób bezrobotnych, w szczególności zagrożonych wykluczeniem społecznym;

- tworzenie alternatywnego systemu ekonomicznego i społecznego.

Ekonomia społeczna ma zatem na celu z jednej strony reintegrację społeczną i zawodową osób wykluczonych, a z drugiej strony koncentruje się na pobudzaniu demokracji i partycypacji społeczności lokalnych, jak również podnoszeniu spójności lokalnej gospodarki poprzez produkcję dóbr i usług. Uzupełnieniem tego podejścia może być koncepcja zaproponowana przez B. Roelantsa, która nawiązuje nie tylko do wartości solidarności, odpowiedzialności i aktywnego obywatelstwa, ale także wskazuje na takie cechy, jak tworzenie miejsc pracy o wysokiej jakości, podnoszenie poziomu życia, działanie na rzecz rozwoju lokalnego i spójności społecznej [Pokora, 2014].

W przypadku wsparcia funkcji rodziny poprzez organizację usług opiekuńczych na rzecz osób starszych główną rolę odgrywać będzie dostarczanie usług socjalnych dla jednostek i wspólnot lokalnych. Powstawanie nowych przedsiębiorstw społecznych dostarczających takie usługi przyczyniać się będzie do tworzenia miejsc pracy, a to pośrednio będzie wpływać na reintegrację społeczną i zawodową jednostek. Usługi opiekuńcze na rzecz rodziny zajmującej się starszym członkiem rodziny są niszą, która może być zagospodarowana przez podmioty ekonomii społecznej. We współczesnej polskiej rodzinie opieka nad dzieckiem i starszymi członkami rodziny jest głównie domeną kobiet, które równolegle podejmują także pracę zarobkową. Niestety rodzi to konsekwencje związane z nadmiarem obowiązków, brakiem czasu i przemęczeniem. Wsparcie instytucjonalne jest niewystarczające, dlatego też nadal w polskiej rodzinie dominuje model wsparcia wewnątrzrodzinnego, które tylko pozornie jest oszczędne, w konsekwencji rodzi jednak wysokie koszty. Do najważniejszych kosztów tego typu należy zaliczyć [Kotowska, Sztanderska, Wóycicka, 2007]:

- poważne obciążenie funkcjami opiekuńczymi osób dorosłych, w szczególności kobiet;

- postępujący proces starzenia się ludności prowadzi do rosnącego zapotrzebowania na opiekę nad osobami starszymi, którą jeszcze do niedawna mogły sprawować osoby w wieku przedemerytalnym, pobierające wcześniejsze świadczenia. Zmiany w systemie emerytalnym ograniczają dostęp do wcześniejszych emerytur i silniej wiążą ich wysokość z wiekiem przejścia na emeryturę. W konsekwencji seniorzy w Polsce coraz mniej będą mogli liczyć na bezpłatną opiekę krewnych.

Te dwa główne problemy dotyczące wypełniania funkcji opiekuńczej przez kobiety w rodzinie skłaniają do refleksji nad przyszłością polityki społecznej państwa w zakresie wsparcia funkcji opiekuńczej rodziny, dając jednocześnie duży obszar do zagospodarowania dla przedsiębiorczości społecznej, która według J. E. Austin definiowana jest jako „działalność innowacyjna, kreująca wartości społeczne, która może występować wewnątrz lub w poprzek sektorów non-profit, biznesu i publicznego" [Mair, Robinson, Hockerts, 2010, s. 158]. Według J. Mair i E. Noboa, którzy określają przedsiębiorczość społeczną jako „innowacyjne wykorzystanie kombinacji zasobów w poszukiwaniu możliwości tworzenia organizacji i/ lub podejmowania działań, które przynoszą i utrwalają korzyści społeczne"[ibidem], tworzenie przedsiębiorstw społecznych wspierających funkcje opiekuńcze rodziny jest dużą szansą na dalszy rozwój trzeciego sektora. Jest to obszar niszowy i bardzo ważny do zagospodarowania. Dotyczy on wsparcia nie tylko seniorów niesprawnych funkcjonalnie, terminalnie chorych, ale również seniorów z zaburzeniami pamięci. Istotną rolę mogą tu odegrać np. spółdzielnie socjalne. Idee 
te powinny być szczególnie propagowane w mniejszych miastach, gminach wiejskich, gdzie dostęp do usług opiekuńczych jest utrudniony i rodziny są skazane głównie na pomoc najbliższych czy też sąsiadów. Zakładanie spółdzielni socjalnych może nie tylko wspierać w tym przypadku rodziny opiekujące się seniorami, ale również daje szansę na aktywizację zawodową ludności w danej gminie.

W obszarze ekonomii społecznej działają przedsiębiorstwa społeczne, których funkcją, według J. Hausnera, jest nie tylko „wytwarzanie określonych dóbr i usług, ale też mobilizacja kapitału społecznego, generowanie innowacyjności oraz poszerzanie rynku przez włączanie do uczestnictwa w nim osób dotychczas wykluczonych. Przedsiębiorstwo społeczne jest cząstką rynkową, ale specyficzną, bowiem lokującą swoją misję i cele poza rynkiem. Uczestniczy w gospodarce rynkowej, ale według specyficznych reguł, co różni je od przedsiębiorstwa prywatnego" [Hausner, Laurisz, Mazur 2008, s. 9]. Według E. Leś do podstawowych funkcji przedsiębiorstw społecznych zalicza się [Leś, 2009, s. 365]:

- „funkcję reprezentowania interesów i praw (rzecznictwo), adresowaną do państwa, rynku lub/i społeczeństwa;

- funkcję redystrybucyjną, umożliwiającą wykorzystanie w celach dobra wspólnego zasobów, które inaczej nie byłyby wykorzystane do zaspokojenia potrzeb społecznych;

- funkcję produkcyjną, ukierunkowaną na zaspokojenie potrzeb lokalnych w zakresie usług, w tym umożliwienie tego grupom, które nie mogą zakupić ich na rynku".

Funkcje jakie spełniają przedsiębiorstwa trzeciego sektora są zatem alternatywą dla polityki społecznej w zakresie wspierania funkcji opiekuńczej rodziny, z uwzględnieniem elementu opiekuńczego nad osobą starszą $w$ rodzinie.
Przedsiębiorstwo społeczne jest prywatną, niezależną organizacją dostarczającą produktów lub usług na rzecz szerszej społeczności, którego założycielem albo zarządzającym jest grupa obywateli. Nadwyżka zysków z prowadzonej działalności może być przeznaczona na stały rozwój celów i usług dla członków lub wspólnych zadań. Przedsiębiorstwo to cechuje się autonomicznym zarządzaniem i niezależnością od władz państwowych. Jest ono gotowe do podejmowania ryzyka ekonomicznego, które związane jest z prowadzoną działalnością społeczno-ekonomiczną [Pikuła, Jagielska, 2014].

Rozważania na temat przedsiębiorczości społecznej najpełniej podsumowują słowa M. Grewińskiego, który twierdzi, że: „przedsiębiorczość to nie tylko postawa i działalność ekonomiczna, ale także społeczna, która realnie przyczyniać się może do zwiększania dobrobytu społecznego i społecznej szczęśliwości wielu grup zagrożonych wykluczeniem społecznym. Działania podmiotów gospodarki społecznej to praktyczne dowody i jednocześnie argumenty, które wpisują się w trwającą dyskusję i poszukiwanie najbardziej adekwatnej definicji i roli dla przedsiębiorczości społecznej, co wydaje się być zamierzeniem trudnym, a jednocześnie niezbędnym ze względu na znaczenie tego zjawiska dla rozwoju współczesnych społeczeństw, borykających się z wieloma problemami społecznymi" [Grewiński, 2012].

Ekonomia społeczna jest na pewno alternatywą dla zagospodarowania działań opiekuńczych na rzecz seniora. Praca z osobą starszą m.in. z zaburzeniami pamięci, niesprawną fizycznie jest bardzo trudnym i niestety mało atrakcyjnym zadaniem. Nie zmienia to jednak faktu, że wprowadzenie tych usług na rynek pracy jest w obecnej sytuacji demograficznej Polski wręcz niezbędne. Prognozy demograficzne są dla Polski niezbyt optymistyczne. Przekładają się one na przewidywane pogorszenie się sytuacji na rynku pracy. Polacy będą musieli pracować dłużej. 
Rezygnacja z pracy na rzecz sprawowania opieki nad starszym członkiem rodziny może oznaczać np. uzyskanie niższych świadczeń emerytalnych, co wygeneruje nam pokolenie seniorów uzależnionych od systemu pomocy społecznej. Istotne jest zatem wykorzystanie potencjału podmiotów ekonomii społecznej do wsparcia rodziny właśnie w zakresie opieki nad osobą starszą. Usługi te powinny być optymalnie dopasowane do potrzeb osób starszych i wspierać ich w prowadzeniu gospodarstwa domowego. W ramach świadczonych usług przedsiębiorstwa trzeciego sektora mogłyby np. stworzyć system dostarczania posiłków osobom niemogącym samodzielnie ich przygotowywać. Rozwiązaniem dla rodzin opiekujących się niesprawnym seniorem mogą być również mieszkania chronione, w których senior miałby zapewnioną całodobową opiekę i jednocześnie brałby udział w zajęciach aktywizujących. Wsparcie rodziny w opiece nad seniorem to nie tylko pomoc w opiece w miejscu zamieszkania. Ważne jest również zorganizowanie opieki dla rodziny. Organizacje pozarządowe mogłyby tworzyć centra opieki krótkoterminowej oraz organizować pomoc psychologiczną dla rodziny opiekującej się starym, schorowanym seniorem. Istotną rolę wspierającą funkcje opiekuńcze mogą tworzyć placówki dziennego pobytu, kluby seniora, centra aktywności seniora [Błędowski, Szatur-Jaworska, Szweda-Lewandowska, Zrałek, 2016]. Przegląd działalności PES wskazuje na ich dużą aktywność w zakresie aktywizacji, edukacji seniorów. Jako przykład można podać m.in. fundacje i stowarzyszenia prowadzące Uniwersytety Trzeciego Wieku, Kluby Seniora, Centra Aktywności Seniorów itp. Świadczenie usług opiekuńczych w miejscu zamieszkania jest przedmiotem działalności m.in. spółdzielni socjalnych. Informacje na temat działalności spółdzielni socjalnych w zakresie usług opiekuńczych w poszczególnych województwach można odnaleźć na stronie: http://www.spoldzielniesocjalne. org/kzdrowie2.htm [za: Perek-Białas, 2013].

\section{Podsumowanie i rekomendacje}

Podmioty ekonomii społecznej stanowią ważne ogniwo w rozwoju usług na rzecz wspierania funkcji opiekuńczej rodziny. Nie dotyczy to jednak tylko i wyłącznie usług świadczonych na rzecz dzieci, gdyż wsparcie rodziny w tym zakresie jest coraz lepsze, ale powinno skoncentrować się na opiece nad starszymi członkami rodziny. Jak słusznie zauważa J. Perek-Białas, przed podmiotami ekonomii społecznej „stoi wiele wyzwań spowodowanych zmianami demograficznymi, w tym starzeniem się ludności. To właśnie starzenie się ludności powoduje, że należy oczekiwać wzrostu popytu na nowe usługi społeczne kierowane do osób starszych, których będzie coraz więcej w społeczeństwie. Potrzebne będą nie tylko zmiany w zakresie usług dostarczanych przez instytucje publiczne - do tych zmian musi się dostosować rynek, a także organizacje pozarządowe oraz podmioty ekonomii społecznej. Ważne, aby świadomość zmian demograficznych była obecna w dalszych działaniach sektora ekonomii społecznej w Polsce, traktując starzenie i starość jako szansę na rozwój swojej działalności, a nie jako kłopot czy zagrożenie. To zmiana myślenia o starzejących się populacjach i możliwościach wykorzystania zjawiska starzenia się ludności jest najbardziej potrzebna" [Perek-Białas, 2013, s. 72].

Szczególny nacisk powinno się położyć na tworzenie usług opiekuńczych na rzecz osób starszych i niepełnosprawnych, świadczonych w miejscu zamieszkania, ponieważ są niejednokrotnie lepszą alternatywą aniżeli opieka instytucjonalna. Niejednokrotnie to nie instytucjonalne wsparcie zabezpiecza podstawowe potrzeby osób starszych, ale wsparcie w miejscu zamieszkania np.: pomoc w robieniu zakupów lub w podstawowych pracach domowych. Usługi świadczone na 
rzecz seniorów powinny przede wszystkim odpowiadać i zaspokajać ich potrzeby. Sytuacja komplikuje się jeszcze bardziej w przypadku, kiedy dzieci mają pod opieką swoich rodziców oraz dziadków, a także swoje wnuki. Dlatego warto wziąć pod uwagę wskazane wcześniej czynniki, ponieważ kompleksowe wsparcie w sprawowaniu opieki przyniesie korzyści nie tylko rodzinom opiekującym się

\section{Literatura}

Błędowski P., Szatur-Jaworska B., Szweda-Lewandowska Z., Zrałek M. (2016). „Model wsparcia społecznego osób starszych w środowisku zamieszkania", w: B. Szatur-Jaworska, P. Błędowski (red.), System wsparcia osób starszych w środowisku zamieszkania. Przegląd sytuacji, propozycja modelu (s. 13-46). Warszawa: Biuro Rzecznika Praw Obywatelskich.

Grewiński M. (2012). „Gospodarka społeczna w UE i w Polsce - między przedsiębiorczością społeczną a CSR", w: Przedsiębiorczość - stan i perspektywy. Warszawa: WSP TWP w Warszawie.

GUS (2016). Ludność w wieku 60 lat i więcej. Warszawa: Główny Urząd Statystyczny.

Hausner J., Laurisz N., Mazur S. (2007). „Przedsiębiorstwo społeczne - konceptualizacja", w: J. Hausner (red.), Zarządzanie podmiotami ekonomii społecznej (s. 7-20). Kraków: MSAP UEK.

Kawula S. (1999). „Rodzina jako grupa i instytucja opiekuńczo-wychowawcza", w: S. Kawula, J. Brągiel, A. Janke (red.), Pedagogika rodziny. Toruń: Wyd. Adam Marszałek.

Kawula S. (1999). „Wsparcie społeczne”, w: D. Lalak, T. Pilch (red.), Elementarne pojęcia pedagogiki społecznej i pracy socjalnej (s. 338-341). Warszawa: Wydawnictwo Akademickie "Żak".

Kotowska I.E., Sztanderska U., Wóycicka I. (2007). Między domem a praca. Rekomendacje dla polityków. Warszawa: Wydawnictwo Naukowe SCHOLAR.

KPRES (2014). Krajowy Program Rozwoju Ekonomii Społecznej. Warszawa: Ministerstwo Pracy i Polityki Społecznej, Zespół ds. Rozwiązań Systemowych w Zakresie Ekonomii Społecznej, www.pozytek. gov.pl/download/files/KPRES_30.04.2014_ost.pdf (dostęp: 13.09.2017).

Leś E. (2009). „Rola trzeciego sektora w polityce społecznej", w: G. Firlit-Fesnak, M. Szylko-Skoczny, Polityka społeczna. Podręcznik akademicki. Warszawa: Wydawnictwo PWN.

Maciarz A. (2005). Mały leksykon pedagoga specjalnego. Kraków: Wydawnictwo "Impuls". osobami starszymi, ale również w sposób pośredni może przyczynić się do reintegracji zawodowej poprzez tworzenie miejsc pracy w organizacjach trzeciego sektora świadczących usługi opiekuńcze na rzecz osób starszych. Dzięki takim działaniom ekonomia społeczna odegra ważną rolę w systemie wsparcia rodziny.

Mair J., Robinson J., Hockerts K. (2010). Przedsiębiorczość Społeczna. Warszawa: WSP TWP w Warszawie.

Olubiński A. (1997). „Wsparcie społeczne w pracy socjalno-wychowawczej - zarys problematyki", w: E. Kantowicz (red.), Wsparcie społeczne w różnych układach ludzkiego życia (s. 18-26). Olsztyn: Wydawnictwo Studium Kształcenia Ustawicznego "Glob”.

Pankiv O., Duranowski W. (2014). Przedsiębiorczość społeczna a praca socjalna. Warszawa: Centrum Rozwoju Zasobów Ludzkich.

Perek-Białas J. (2013). "Starzenie się ludności wyzwanie dla podmiotów ekonomii społecznej", Ekonomia Społeczna, nr 2 (7).

Pikuła N., Jagielska K. (2014). „Ekonomia społeczna w kontekście wyzwań rynku pracy", Labor et Educatio, nr 2.

Pokora M. (2014). „Ekonomia społeczna w polityce przeciwdziałania wykluczeniu społecznemu w Polsce", Ekonomia Społeczna, nr 2.

Sałustowicz P. (2006). „Koncepcje i funkcje ekonomii społecznej", w: P. Sałustowicz, H. Guzowska (red.), Ekonomia społeczna a bezradność społeczna - perspektywy i bariery. Warszawa: Biuro Rzecznika Praw Obywatelskich.

Sęk H., Cieślak R. (2011). „Wsparcie społeczne sposoby definiowania, rodzaje i źródła wsparcia, wybrane koncepcje teoretyczne", w: H. Sęk, R. Cieślak (red.), Wsparcie społeczne, stres i zdrowie (s. 11-28). Warszawa: PWN.

Szatur-Jaworska B. (2016). Polska polityka społeczna wobec starzenia się ludności w latach 1971-2013. Warszawa: Dom Wydawniczy ELIPSA.

Tyszka Z. (1991). Z metodologii badań socjologicznych nad rodzinq. Poznań: Ministerstwo Edukacji Narodowej.

Ustawa z dnia 11 lutego 2016 roku o pomocy państwa w wychowywaniu dzieci (Dz.U. 2016 poz. 195 z późn. zm.).

Ustawa z dnia 9 czerwca 2011 roku o wspieraniu rodziny i systemie pieczy zastępczej (Dz.U. 2013 poz. 135 z późn. zm.).

Ustawa z dnia z 12 marca 2004 roku o pomocy społecznej (Dz.U. 2004 nr 64 poz. 593 z późn. zm.). 
WHO (2011). Global Health and Ageing. Geneva: World www.pck.pl. Health Organization/National Institute on Ageing.

\section{Social economy as an important link in the family support system}

Summary: Issues related to the transformation of modern family are one of the important problems in the field of social policy. This article focuses on the problems arising from demographic change - particularly the ageing of the population, which consequence is the increasing importance of the family's caring role to its oldest members. Social economy plays an important role in this area, becoming an important factor in the family help and support system. Social enterprises can support families by providing care services for the elderly. This is an important aspect in the case of the ageing of Polish society. With age, functional capacity decreases, and multiple diseases develop. This results in an increasing demand for care services for the elderly. Services dedicated to seniors under the social welfare and health care systems do not meet the needs for all those who need them. Therefore, a need to look for new solutions in this area exists.

Keywords: social support, social economy, family, senior care.

\section{Prawa autorskie i licencja / Copyright and License}

Artykuł opublikowano na licencji Creative Commons Uznanie autorstwa - Użycie niekomercyjne - Bez utworów zależnych 3.0 Polska http://creativecommons.org/licenses/by-nc-nd/3.0/pl/

This article is published under the terms of the Creative Commons Attribution - NonCommercial - NoDerivs (CC BY-NCND 3.0) License http://creativecommons.org/licenses/by-nc-nd/3.0/ 